\title{
Glycoprotein of Human Rotavirus Wa Strain Grown in MA104 Cells
}

\author{
Osamu Nakagomi, Toyoko Kutsuzawa-Nakagomi, * \\ Tsunehisa Suto, ${ }^{*}$ Tasuke Konno $†$ and Nakao Ishida \\ Department of Laboratory Medicine, Akita University Hospital, \\ * Department of Microbiology, Akita University School of \\ Medicine, Akita 010, †Department of Pediatrics and \\ † Department of Bacteriology, Tohoku University School of \\ Medicine, Sendai 980
}

Nakagomi, O., Kutsuzawa-Nakagomi, T., Suto, T., Konno, T. and Ishida, N. Glycoprotein of Human Rotavirus Wa Strain Grown in MA104 Cells. Tohoku J. exp. Med., 1983, 139 (4), 423-424 — Eight distinct polypeptides with molecular weights of 130,000 (130 K, VP1), $96 \mathrm{~K}$ (VP2), $84 \mathrm{~K}$ (VP3), $80 \mathrm{~K}$ (VP4), $56 \mathrm{~K}$ (VP5), $40 \mathrm{~K}$ (VP6), $35 \mathrm{~K}$ (VP7) and $28 \mathrm{~K}$ (VP8) were identified in human rotavirus (Wa strain) particles. Only VP7 was glycoprotein possessing high-mannose type oligosaccharide chain(s). Tunicamycin markedly suppressed the incorporation of $\left[{ }^{3} \mathrm{H}\right]$ glucosamine into the VP7. This glycosylation pattern is very similar to that reported in simian rotavirus SA11. glycoprotein; human rotavirus;

Wa strain; polypeptides

Human rotavirus (HRV) research is currently focused on the serotyping of HRVs by neutralization assays. Since the neutralization specificity often resides in glycoproteins in other virus systems, we examined the polypeptide components of HRV Wa strain with special attention to their glycosylation pattern.

Monolayer cultures of MA104 cells were infected with Wa virus at multiplicity of 0.5 TCID $_{50}$ per cell. After $6 \mathrm{hr}$ postinfection, the medium was changed to leucine-free Eagle's minimum essential medium containing $0.5 \mu \mathrm{g} / \mathrm{ml}$ of trypsin and $5 \mu \mathrm{Ci} / \mathrm{ml}$ of $\left[{ }^{14} \mathrm{C}\right]$ leucine. The infected cultures were harvested $24 \mathrm{hr}$ after infection, frozen and thawed, then centrifuged at $59,000 \times \mathrm{g}$ for $5 \mathrm{hr}$. The resulting pellet was suspended in $0.01 \mathrm{M}$ Tris- $\mathrm{HCl}$, $0.15 \mathrm{M} \mathrm{NaCl}, 0.001 \mathrm{M} \mathrm{MgCl}_{2}, \mathrm{pH} 8.0$ and incubated at $37^{\circ} \mathrm{C}$ for $1 \mathrm{hr}$ with rabbit anti-Wa serum (Nakagomi et al. 1982). To this was added a 10\% suspension of Staphylococcus aureus Cowan I strain and incubated at $37^{\circ} \mathrm{C}$ for $1 \mathrm{hr}$, followed by three washings in $0.05 \mathrm{M}$ Tris$\mathrm{HCl}$, 0.1 $\mathrm{M} \mathrm{NaCl}$, pH 7.4 containing $0.1 \%$ Triton $\mathrm{X}-100$ and another three washings in distilled water. $\left[{ }^{3} \mathrm{H}\right]$ Glucosamine-labeled virus was prepared in a similar fashion in the presence or absence of tunicamycin $(2 \mu \mathrm{g} / \mathrm{ml})$ and immunoprecipitated as described above. These immunoprecipitates were subjected to SDS-PAGE as described previously (Nakagomi et al. 1981).

Fig. 1 is a representative profile of SDS-PAGE which resolves eight distinct polypeptides with molecular weights of 130,000 (130 K, VP1), $96 \mathrm{~K}$ (VP2), 84 K (VP3), $80 \mathrm{~K}$ (VP4), $56 \mathrm{~K}$ (VP5), $40 \mathrm{~K}$ (VP6), $35 \mathrm{~K}$ (VP7), $28 \mathrm{~K}$ (VP8) in Wa virus particles. The corresponding Rodger's designations (Rodger et al. 1975) are shown in parentheses. Only the VP7 incorporated $\left[{ }^{3} \mathrm{H}\right]$ glucosamine and tunicamycin markedly suppressed this glucosamine incorporation into the VP7 (Fig. 2). Similar experiments revealed that $\left[{ }^{3} \mathrm{H}\right]$ mannose, but not $\left[{ }^{3} \mathrm{H}\right]$ galactose, was incorporated into the VP7 (data not shown). This indicated that the VP7 contained a high-mannose type oligosaccharide chain(s).

Concerning the glycoprotein of human, calf, and simian rotaviruses, Rodger et al. (1977) showed that p26 (corresponding to VP7) and p21 (VP8) of human rotavirus, p22 of calf, and

Received for publication, September 27, 1982. 
p23 of simian rotaviruses are glycosylated. Recently, Arias et al. (1982) and Erickson et al. (1982) demonstrated by examining the incorporation of radioactive sugar precursors that simian rotavirus SA11 possesses one structural glycoprotein (VP7) with a molecular weight of $38 \mathrm{~K}$ which has a high-mannose type oligosaccharide chain(s). Our present experiments confirmed that a similar glycosylation pattern of structural polypeptide of virus particles occurred in the HRV.

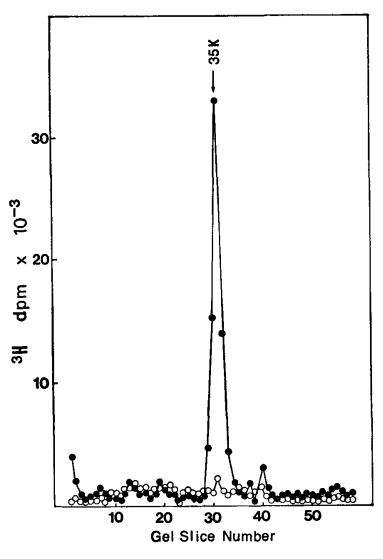

Fig. 1

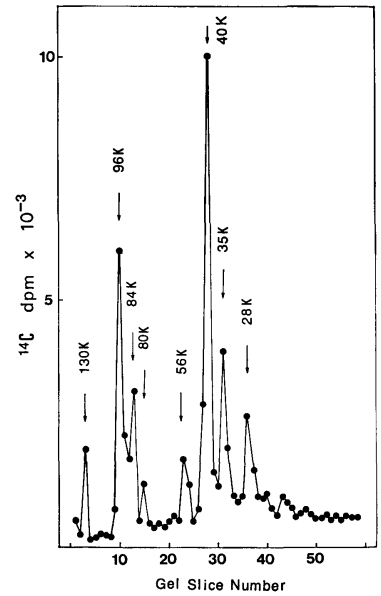

Fig. 2

Fig. 1. Polypeptide composition of Wa virus. The Wa virus was grown in MA104 cells in the presence of $\left[{ }^{14} \mathrm{C}\right]$ leucine and immunoprecipitated with anti-Wa serum. The radioimmunoprecipitated virus was subjected to SDS-PAGE as described in the text. Eight distinct polypeptides with molecular weights of $130,000(130 \mathrm{~K}), 96 \mathrm{~K}, 84 \mathrm{~K}$, $80 \mathrm{~K}, 56 \mathrm{~K}, 40 \mathrm{~K}, 35 \mathrm{~K}$, and $28 \mathrm{~K}$ were identified as indicated by arrows in the figure.

Fig. 2. $\left[{ }^{3} \mathrm{H}\right]$ glucosamine incorporation into the viral polypeptides. The Wa virus was grown in MA104 cells in the presence of $\left[{ }^{3} \mathrm{H}\right]$ glucosamine either in the absence or presence of tunicamycin $(2 \mu \mathrm{g} / \mathrm{ml})$. $\left[{ }^{3} \mathrm{H}\right]$ Glucosamine incorporation into the $35 \mathrm{~K}$ polypeptide, VP7, (-•) was markedly suppressed in the presence of tunicamycin (०-०).

\section{References}

1) Arias, C.F., Lopez, S. \& Espejo, R.T. (1982) Gene protein products of SA11 simian rotavirus genome. J. Virol., 41, 42-50.

2) Erickson, B.L., Graham, D.Y., Mason, B.B. \& Estes, M.K. (1982) Identification, synthesis, and modifications of simian rotavirus SAll polypeptides in infected cells. J. Virol., 42, 825-839.

3) Nakagomi, O., Shiraishi, H., Yamada, E., Nakagomi, A. \& Ishida, N. (1981) Glycoprotein of hepatitis B surface antigen (HBsAg) produced by PLC/PRF/5 hepatoma cells. Microbiol. Immunol., 25, 617-621.

4) Nakagomi, O., Nakagomi, A., Suto, T., Suzuki, H., Kutsuzawa, T., Tazawa, F., Konno, T. \& Ishida, N. (1982) Detection of human rotavirus by reversed passive hemagglutination (RPHA) using antibody against a cultivable human rotavirus as compared with electron microscopy (EM) and enzyme-linked immunosorbent assay (ELISA). Microbiol. Immunol., 26, 747-751.

5) Rodger, S.M., Schnagl, R.D. \& Holmes, I.H. (1975) Biochemical and biophysical characteristics of diarrhea viruses of human and calf origin. J. Virol., 16, 1229-1235.

6) Rodger, S.M., Schnagl, R.D. \& Holmes, I.H. (1977) Further biochemical characterization, including the detection of surface glycoproteins, of human, calf, and simian rotaviruses. J. Virol., 24, 91-98. 